\title{
Museum, Education and Visual Culture Practices: Museums in Turkey
}

\author{
Zekiye Çıldır, Ceren Karadeniz ${ }^{*}$ \\ Master of Science, Doctorate student at Ankara University, Institute of Educational Sciences, Department of Cultural Foundations of \\ Education/ Fine Arts Education, Ankara, Turkey \\ *Corresponding author: ckaradeniz@ankara.edu.tr
}

Received June 04, 2014; Revised July 02, 2014; Accepted July 13, 2014

\begin{abstract}
Modern approach evolved modern museums as dialogue centres which make close contact with visitors based on learning in order to present its exhibition objects. Along with twenty first century, being one of the most important places among the social functions of museums, "education" has almost been one of the traditional functions of them. Besides the educational facilities which museums provide visitors, they should also develop their physical structures in a contemporary line, and reconsider them in a way that highlights individual experience and visitor interaction during the time spent in there. In order to maximize interaction between visitors and museums, museum education which is developed by using pedagogical methods and grounding on various values, concepts and information has a close relation with visual culture that is an interdisciplinary concept. Visual culture has put popular objects into museums and been an important subject on which modern museums focused in order to provide their sustainability. Modern museums produce information and aim to spread information to all classes in a society by using educational activities; also when they are considered as living places, they are used to practice the functions of visual culture. These practices have been helpful for developing information technologies in museums especially for the last thirty years and, resulted in implementing a structural reform and revisions in regard to integrating these technologies with museum perception. In the frame of these revisions, online technologies, simulations, interactive presentations and digital exhibitions are at the first place. These chances that took place in museums have been the source for from the collections of these institutions to their policies and also from the use of human resources to digitalizing of their activities. The purpose of this study is to identify the visual culture activities which take place in modern museums in the framework of educational activities, and to display practice samples in Turkish museums in detail. The study is a result of a descriptive survey model research that contains samples regarding visual culture practices in the world and Turkish museums. The study is limited with state and private museums which are tied to Turkish Republic Ministry of Culture and Tourism and inspected by the relevant ministry. Visual culture practices that took place in these museums are gathered by using structured interview forms and commented by analyzing content analysis.
\end{abstract}

Keywords: Format, Microsoft Word Template, Style, Insert, Template

Cite This Article: Zekiye Çıldır, and Ceren Karadeniz, "Museum, Education and Visual Culture Practices: Museums in Turkey." American Journal of Educational Research, vol. 2, no. 7 (2014): 543-551. doi: 10.12691/education-2-7-18.

\section{Introduction}

The main concept of our age, postmodernism, is the part of a cultural evolution and change of sensitivity appearing slowly especially in Western communities. During this modern period called postmodern, a dramatical change has been taking place in formation of sensitivity, practice and discourse at an important part of culture and, this change divides a set of postmodern suggestions, experience and hypothesis from the period before postmodernism. Postmodernism showed itself clearly in urban development, differenciated places, pluralist politics and "collage life" practices which are represented by modern art [1].
The main feature distinguishing human beings from other living creatures is the capacity to conceptualize the world and the ability to communicate through these concepts symbolically. Archeology and cultural anthropology consider culture firstly as a whole of materials produced by human beings [2]; cultural studies and the science of history accept culture as a system of signs or symbols [3]. He emphasizes that nowadays especially cultural anthropologists consider culture as a system of signs or symbols [4]. As being a certain part of culture, visual culture is a combination of research in the fields of philosophy, sociology, anthropology and art studies. Everything we see and envisage fictitiously in the past and today is within visual culture. With its broadest definition, visual culture is a gate opening to the field of culture through communicating with various cultural 
elements by means of images. visual culture is described as "spectacle pedagogy" which teaches us what we see and how we see and think [5].

Visual culture, taking its roots from postmodernism, grounding on hearing and seeing at social communication, is interested in copying digital images and publishing them immediately at an age when originality never exists and even is considered irrational. What is important in visual culture within the context of postmodernism is not the visual itself anymore but the meanings that visual creates regarding individuals, community and the world.

Visual culture studies which cover various areas of cultural and academic disciplines have been creating new paradigms as a visual text that produces visual meanings and interpretations at various contexts - in art works, social areas, educational practices - or towards being understood in different ways as a process of visual communication [6,7]. Bringing many disciplines together visual culture took attention by going beyond art education, and even critical pedagogy; in time it has come to a point where it can create a new occuring area, interdisciplinary in itself. At this new area three main points draw attention: an expanded content which provides a comprehensive list containing images and works, a focus about how and under what circumstances we look at images and works, and studying images within their context as a part of social practice [8].

Nowadays in order to expand the concept of "art culture" and to cover all qualifications of visual culture and digital culture, "visual culture" concept is being used in a way which covers a more broad framework instead of modern research about culture. Visual culture that is a particular part of culture represents visual dimension of culture because it shows itself as coherence of research in philosophy, sociology, antropology and art studies disciplines. Visual dimension of culture contains meanings and values which are created and transmitted by image characteristic of culture. Nowadays it is accepted that people living under visual exposures achieve gainings about art not only in art galleries or museums, but also in every part of every day life. In other words, people are exposed to visual culture stimulus not only in school education but also in every visual experience in every part of life.

\section{Museum and Visual Culture}

Museum which is like a forum helping us to understand who we were, are and will be in the future [9] has continued its existence as a complex and unique social and cultural foundation representing and gathering communities within cultural context, keeping cultural and social records of scientific and artistic achievement [10]. However, this foundation gained a more dynamic and social structure in which collectioners, curators and educators engage in dialogue with audience sometimes implicitly and sometimes more clearly. Related to the cultural mentality of late capitalist period, it supports the personal and environmental evaluation of museum audience who are practising visual culture theory in his system and presents a new path about "looking at" museum object. Being accepted as an educational environment, museum has sensational and intellectual dimensions of education process without any doubt [11]. Traditionally, the purpose of visiting a museum is either to research museum collection or, if the visit is to a historical building, to observe that building in detail and to study any expertise any subject there. A general museum visit in terms of the visitor focuses on either "seeing" and "understanding" an object or providing only visual experience free from thoughts. As a result of these experiences, the primary education in museums has evolved to a sensual and effective education.

Museums and galleries are institutions which carry responsibilities to the society and have potentials to affect community life positively. Pulling people into museums and developing cooperation with the public is a process that museums carry out through education nowadays [12]. By the 21st century, educational function of museums is one step ahead from other functions of them. Today's museums are shaped by social, economical and educational changes and now they provide children, older people, women, different ethnic groups, handicapped people, prisoners, etc. with acculturation, learning, socialization and rehabilitation opportunities. These expressions clearly define the function of museums between 1980 and 1990: "balance, echo, liberation, responsibility, island of hope, dialogue, idea platform, social identification, cultural empowering, emotional interaction, re-awakening [13]. Nowadays these expressions have been added to the experience gained in museums, and to the mission and responsibilities of museums: "reflecting oneself, freedom of speech, conflicts, amphiboly, critical thinking, analytical thinking, sensitivity, responsibility, and social responsibility [14,15]. Modern museums consider education as one of the most important functions and they have much to contribute to the society. Besides, museums are modern institutions which ask gripping questions to the audience about the topics they handle and provide a comfortable field service for the audience. These changes in today's museums encourage also cultural institutions such as libraries, archives, theatres, etc to make changes. Museums give up the idea that collections are unchangeable in terms of the future of museum, and they claim that exhibition and presentation are sometimes more important than the object itself. Museum education is an area where today's modern museums display their struggle best for attracting visitors $[16,17]$. Museum education is a museum's visitor centered educational programs in which present collections are used to arouse interest, curiosity and excitement in visitors and activity preparing process which enables practice [18]. Museum education as a lifelong, active, alive, participative and innovative process which relates collections in a museum with the visitors [19]. Museum education is also both a sensorial and intellectual education. Traditionally, the purpose of visiting a museum is either examining that museum collection or, if the visit is to a historical building, observing that building in detail and studying any kind of professional field. In terms of the visitor, a general museum visit is based on observing objects and understanding them or simply providing visual experience free from thoughts [20]. However, the experiences of observing and understanding in a museum can be expanded through the senses of touching, hearing and even smelling. As a result of these experiences, this 
primary education in museums turns out to be a sensorial and effective education.

Within this context, the most common museum services which contain educational activities are museum tours, gallery learning programs out of school (activity fields, museum learning materials, film, video, iphone-ipad and special software for technological devices working with android CPU, etc.) society, adult and family programs (evening activities, speeches - chats, socialization activities, festivals, special days and weeks, meeting artists, etc.), courses (workplace studies, summer and winter programs, museum camps, film displays, performances, private lessons, etc.), cooperation with other institutions and establishments (cooperation with other cities, cooperated projects with schools and universities, school-museum cooperation, etc.), school programs (teacher or instructor booklets, pre-museum and pro-museum activity and evaluation resources and forms, suitcase museum activities for schools, replication materials, conferences in schools, etc.), online educational programs (online games, lessons, seminars, conferences and workshops, online exhibition catalogs and educational sheets).

In a museum environment, at educational process using visual culture discourses especially as an objective (lens) at evolving looking practice, free areas where audiences can discuss both art objects and their social relations can be created. Necessity of making sense of objects should be considered actively instead of observing them passively [21]. By focusing on how to look at objects at visual culture works in museums and making suitable arrangements, images that are part of the practice can be studied. Because visual culture reaches a broader content with the meanings attached to visual objects and general rules of visual culture, instead of visual objects. According to Freedman [22] forms of visual culture are represented by means of people's thoughts. According to an educator's viewpoint, it is crucial to understand the importance of representation because by enriching students' experiences with art we can help structuring information directly. Hovewer, this enrichment can be directed in a limited way.

Visual culture discourses contribute to the structure of learning and educational experience in a museum. Global culture which is full of visuals is moving towards visual based communication. Visual culture is being seen on TV, bilboards, computers, in museums, magazines, cinemas, malls, etc. and felt strongly. Museums are important places for change. Thus, they present dynamic practice and watching environments for new developed theories about both education and art. Considering the concepts which are in visual culture discourses, the importance of analysing how individuals see an object and experience it, and in what context they connect to an object can be understood. Museum educators often practice this looking action by this way. Activities like visiting museums or art galleries outside of school environment are more permanent. Especially art education which is structured in postmodern art mentality axis can reveal different interpretations and viewpoints when practising not only with the perspective of Western art but also implementing other cultural richness. As the purpose of modern art education is to identify cultural richness of visual arts, to help students learn the relations between traditional and modern art forms by using extrascholastic learning environments.

Although in practice traditional museum studies mentality keeps its influence, nowadays museums should develop new communication strategies for reaching their audiences, create alternative exhibition atmospheres to fulfill visual culture and develop new relation forms for culture consumers who wish to reach information in a short way [23]. These foundations that have a productive potential in terms of art education play important roles in the process of developing interest towards art in society. In studies concerning museum, it is often emphasized the relation between museum and "memory" as both a concept and an environment. We need to make a connection between memory art and techniques and visual facilities in museums. In a museum which is a memory environment, objects talk about themselves and museum object is open to different readings by receptors in every way [24].

The meaning of an image changes as regards the objects coming just before or just after it. The power that image carries means that it spreads the whole context in which it is seen [25]. The existence of museum object in a museum environment creates a different aura there, and gains various meanings and roles according to the subject studied in that museum. The purpose of displaying in museums is often to forget what is real, to take object out of its every day functional context in which it exists at first, so increase its diversity and to ensure it to make a potential dialogue with other ages [26]. That takes us to see museum object not only as an ordinary piece of information, but also as a historical hieroglyphics; to a museum object concept whose reading needs a memory action, and which takes historical distance and temporal transcendency aura from its materiality. Quick spread of popular culture, acceleration of multimedia and globalisation processes changed art culture mentality. Development of technologies and new communication forms also enabled the progress and spread of art culture more easily. New suggestions are made about that art education which can be given as an another problem area of postmodern art education should be restructured as visual culture education instead of traditional art education.

\section{Use of Technology and Digital Learning in Museums in the Context of Visual Culture}

Various elements of visual culture offer a metaphoric richness that enables referring to interesting topics in terms of the experiences of museum visitors. This experience includes what the visitors know about life and ideas and what they experience in their every day lives emotionally. Visual dimension of culture contains meanings and values which are created and transmitted by image characteristics of culture. All the cultures have a visual dimension. The number of the visual culture studies which analyze and interpret visual experience structures, their functioning in different social systems and every day activities is increasing continuously [19].

In visual culture studies in the museums, images as being a part of practice are researched by emphasizing how to look at the objects and by making necessary arrangements. Visual culture is more than objects; rather, 
it has been expanded with the meanings attached to visual objects and general rules of visual culture. The forms of visual culture are represented through the ideas of humans. According to the views of an educator, it is important to understand the significance of representation because we can help the construction of information directly by enriching the experiences of students through art. Education is necessary in order to reach inner meanings of a visual, to understand and value a piece of art and to create a piece of art. The only way to reach deep and real meanings of visual culture world around us is through education. The use of museum technologies enables interpreting objects with new methods by providing new dimensions to the functions of museums, to the interaction between museum and visitors, to the interaction and communication between visitor and object. When the audience meets museum environment physically, in order to leave him/her alone with the exhibition, to provide a free choice learning environment and to make the act of watching an object attractive, the use of multimedia devices in museums has become more common. Today, museums exhibit objects at a less number in interactive exhibition environments with the help of technology. In these exhibitions, personal or social stories and memories are presented through video or film presentations. The museums made their collections as touch screen and interactive with the support of technological developments and so, they achieved to reach every kind of visitors from each age group.

With online use of broad participated, interactive and 3 dimensional virtual environment, numeral technologies can be distributed in virtual environments over an online network without facsimile of art works necessarily, and they can be exhibited through virtual museums without any geographical boundaries. In addition to these possibilities, a virtual art environment having its own rules is created for art that always seeks new forms of expression [28]. Virtual reality practices are systems which can be used effectively in distance education systems on the condition that necessary infrastructure is provided. Such that, it enables interaction between elements and people in virtual world with its opportunities such as meeting people at distant places in a virtual environment and addressing their senses like sound, image and touching in an imitated version of physical world. Active usage of visual, auditory and tactual possibilities of virtual reality technology in education of art history can contribute to the quality of education by increasing effectiveness and permanence of it.

Within the framework of modern museum practices, today's museums can be considered as living places which produce information, display information about objects by evaluating them, and aim to convey information to all classes in a society by using educational activities. Museums that adapted modern approaches can be successful foundations as long as they realize structures which can be formed within the framework of time-place based circumstances, possibilities and needs prudentially. In museums structural reforms and innovations have taken place especially for the last thirty years due to the developments in information technologies. These changes have been the source for digitalizing museums from museum collections to their policies and from the use of human resources to their activities.
Museums started to become rational learning environments by trying to present educational information sources to mass public instead of serving to a limited population; they changed their collections into a form that people can touch and interact with them by taking support of technological developments, and thus they have been displaying a profile that can reach audiences from every age group. Modern museums whose target group is primarily children, the young and families are not only child-friendly institutions anymore, but at the same time they know their visitors well, they are family-friendly which prepare families to museum visits, and technologyfriendly foundations that offer and present technological facilities to visitors.

Modern museums focused on face-to-face teaching method for museum education but they also pay attention to mass communication in order to take attention of visitors, increase the number of visitors, promote museums and exhibitions. It is becoming popular among museums to use technology for realising mass communication. Today most of the museums are realising their mass communication by special exhibitions on websites, virtual museum applications, direct museum publications or museum web castings, museum education sets prepared for teachers, lending services, mobile museum services, videos and mainly visual museum practices. At Samsung Digital Discovery Centre in British Museum, interactive and free family activities in which computer technology is used are arranged every weekend. The museum makes connection between these activities at digital centre and educational work which they prepare and implement connected with museum collections at continuing education centre. In the museum a set of educational activities about mosaic masks belonging to Aztec Emperor Moctezuma was held in 2009-2011. Guided museum tours, seminars and similar museum educational activities connected to the same exhibition are held at the part of the museum where Latin American Aztec-Mayan collections are displayed. Inspired by this collection and educational work, Samsung Digital Discovery Centre is arranging "Create Your Own Mosaic Mask” activity to families and children by using tecnological facilities. Within these activities, based on the mosaic masks representing Mayan and Aztec gods (Tezkatlipaca, Tlaloc ve Tonatiuh), sessions are arranged in which digital masks are produced by using smart boards and computer screens. London Museum is preparing an educational activity called "Old and New Stories" with digital support. In this activity children are enabled to use camera, barcovision and smart board. Based on the exibitions in the museum, story activities are arranged which enable children to look for some objects in museum galleries. Children who took cameras are following the directions given to them on the museum corridors. Children are supposed to take photograps of a human figure, a mysterious object for them, a place, an animal or an object related to travelling concept. Photographs taken are transferred to digital media and selected by children by using smart board. Children who identify the photographs corresponding to those objects accompanied by the museum educator design their own stories by using visual images at the end of the activity [29].

During this period which was lead by well known brand mark museums, based on the social functions, the first 
technological step in order to reach audiences primarily was virtual museums. Highlighting visuality by means of virtual exhibitions museums are now imaginary foundations without walls for the audience. Virtual (visual) museum is the type of museum which contains numeral objects prepared by using various media facilities; goes beyond traditional communication methods for the purpose of enabling nonstop interaction with visitors and meeting different access forms, and doesn't need a place physically in order to enable access around the world [30]. While these practices can be prepared in the form of internet practices (brochure virtual museum) in which there are general information about an existing museum, the content containing information which aims to present collections online and discovery of collection objects by the visitors can also be prepared. In these examples, an object centred path is being followed and it shows similarity with collection information banks. More preferred visual museum practice by modern museum educators is "educational virtual museum". The presentation of information is content based instead of object based in these practices which enable visitors to enter according to their age, experience and information level. In this kind of virtual museums which are designed to be informative, there are connections that can help visitors get more information about the subjects they are interested in and revisit the site [31]. Virtual museum practices are accepted as important museum technologies because of their opportunities as being open to access worldwide beyond time and place, redefining the communication between museum-audience, being used for the purpose of distance education and lifelong education when they are designed properly, contributing to fill the numerical gap between countries which use information technologies widely and countries which don't and, providing audience with true and reliable information sources.

Communication and promotion opportunity provided by virtual museum practices to museums is also an important chance for highlighting museum object visually and promoting it in detail. On the other hand, it provides an important advantage within the context of museum marketing to museums in order to draw visitors to museums. When audience meets physical environment of museums, the use of multimedia tools in museums is becoming popular in order to leave audience alive with the exhibition, provide him a free-choice learning environment and make seeing a museum object activity more attractive. Some multimedia tools used in museums set perceptions free and give the sense of 'touching' or moving on audience. Effect of these technologies in museums has importance in the interaction between visual and materialistic world. Start of using multimedia in museum foundation allows the transition between two worlds and helps museum foundation renew itself. In this respect, although the purpose of museum exhibitions is to draw attention of audience to objects at first, multimedia tools enable to create a physical, spiritual and emotional area for audience. While the presentation forms of new media art can be generally "mobile" or "onsite"; they can also be mobile phones, Palm/Pilot pocket computers, sensors and Global Positioning System (GPS) that are covered with microphones or tools which provide connections with wireless networks besides projections, computers, screens, DVD players, and they provide digital access and presentation opportunities for art production.

\section{Use of Visual Culture and Technology in Turkish Museums}

In Turkey projects have been prepared in order to constitute technological infrastructure of museums and ruins which are tied to Ministry of Culture since 2000. Within the context of these projects, it is on the agenda to construct brand new pay-desk infrastructures, IP cameras and advertisement display networks, and the use of modern ticketing practices in 48 ruins and museums at first step. Several museums in İstanbul, in Troy, Assos, Ephesus, Knidos antique cities in Aegean Region,in Antalya and in Gaziantep are included in these projects. Internet connection in these museums was provided by using ADSL or 3G technologies based on the infrastructure circumstances in Turkey. These projects were put into practice primarily to modernize museums, provide qualified service to museum visitors, realise advertisement and promotion of museums, and increase the material benefit of the state gained from museums.

The most common museum technology in Turkey is digital information guide and audio headphone systems. In many state museums and private museums these digital information guides serve to the audience. Digital audio and visual guide systems are prepared in Turkish, English, German and French, and they are also being prepared in other preferred languages, and adapted by each museum according to their own qualities by paying attention to their collections. Digitilazing which is made by converting information to numeric data is provided by means of various electronic tools and especially computers. Within this scope, the number of national business realising interactive technologies, simulation, interactive presentation and exhibition designs is increasing in the museums of Turkey. These businesses serve to museums in terms of education, presentation and practices addressing to entertainment industry. Although it is not that common in Turkey yet, some museums use these practices (especially websites and virtual (visual) museum practices). In Çorum Archaeology Museum, Burdur Archaeology Museum, Science Experiment Centre in Eskişehir Science, Art and Culture Park, Eskişehir Hittite Archaeology Museum, Gaziantep Zeugma Museum, Kahramanmaraş Museum, Kaman Museum (Kırşehir), MTA Natural History Museum, Konya Museum, Galata Mevlevi Dervishes Lodge Museum, etc. various effect vision system installations, alive painting practices, 3 dimensioned information systems, stratified holograms, virtual practices, touchscreens, digital books, thematic simulations and virtual workplaces (virtual ceramic and sculpture workplaces, etc.) are used in order to provide interactive museum practices to their audiences [32]. On the website of Ministry of Culture and Tourism, virtual visiting practices to some important historical places within the scope of Ministry such as museum, palace, mosque, fortress, etc. are shared. Among these practices there are 360 degree panoramic tour and virtual museumgallery visits.

Turkish Ministry of Culture and Tourism started reconstruction works in 16 museums in order to renew 
present museums in accordance with modern museum mentality in 2012. In 34 new museums practices and project works are being continued. In these projects it is aimed to address visitor perception by using visuality, informing with scientific content, and technological facilities. Among these museums there are Afyon Karahisar New Archeology Museum, Adana New Archeological Museum, Bitlis Ahlat Museum - Reception Centre, Çanakkale Troy Museum, Denizli New Archeological Museum, Hatay New Archeological Museum, Kayseri New Archeological Museum, Konya New Archeological ve Etnographia Museum, Manisa Archeological Museum, Fethiye Archeological Museum, Şanlı Urfa Archeological Museum, Haleplibahçe Mozaic Museum ve Archeopark, Uşak Archeological Museum and Van - Urartu Museum [33].

\section{Samples for Interactive Museum Practices in Museums}

Research which were made in museums within the scope of Ministry of Culture and Tourism and Museums Head Office show that interactive museum practices are being realised and use of technology is being more popular in some museums that are tied up the Ministry. Etnographic Museum and State Art and Sculpture Museum in Ankara are among these museums which use these practices. Etnographic Museum presents its visitors Virtual Ceramic and Glass Workplace. In order to make visitors experience forming glass and ceramic in Virtual Ceramic and Glass Workplace, a set of touchscreen are installed in the museum, and these touchscreens are prepared as touching the cylindirical mud or glass on the screen and forming it by this way. There are also gun holograms which contain information about the guns that were used in Ottoman and Seljouk, and are being displayed now in the museum. In this practice 3 dimensional modelled guns by using stratified hologram system display an image as if they are on the air. Visitors choose the gun about which they would like to get information on the screen, so they can get detailed information about the history of the object, the use of it and its raw material by means of various animations and 3 dimensional characters.

There is a digital book in the entrance of State Art and Sculpture Museum by which it is aimed to give a general information about history of the museum, its architecture and important art works. Digital book is a practice that contains pictures and animated narration pages which the audience can turn by their hands. Also there is a 3 dimensional model of Art and Sculpture Museum in digital book for visitors to see it in detail. Informing system on Turkish painters which contains a kiosk and a projector gives information to visitors about national artists and art movements chronologically. At the same time this practice serves as a visual catalog which shows the places of art works in the museum. A digital binocular which is placed in the museum garden shows Ankara view in 1930s and allows to watch Ankara panorama from different aspects. The binocular gives information about old buildings that do not exist anymore and new buildings that are built in place of them from their point of view. In Gordion Museum which is in Polatl1, Ankara there is a cylindirical screened virtual visiting system in order to allow visitors to see tumulus and the objects in the king's room onsite. Visitors at first see the tumulus outside, then they get information about the structure of the tumulus, its construction process and its archeological significance by means of interactive information system.

In Zeugma Mosaic Museum in Gaziantep there are touchscreen informing screen, 3D informing film, mosaic completion practice which is served after completing missing parts of mosaic works on display (interactive reflective system) and interactive mosaic pool by means of which it is aimed to present a work similar to the use of it during its own time. These mosaics used to be in pools which were used for gathering rain water in the middle of Zeugma's Roman houses. Kahramanmaraş Museum animates extinct Maraş Elephants with an interactive presentation by means of 3D panoramic living simulation. Paleolitic Era is represented by interactive reflectors which animates sequences from the life of a caveman getting warm by the fire in an artificial cave representing Direkli Cave in the museum. Besides these, the oldest terra-cotta Mother Goddess Sculpture of Asia Minor and Anatolia is presented in the museum as a $3 \mathrm{D}$ virtual object by means of hologram technique. In Çorum Museum there are chariot simulator practices which allow a visit Hattuşa Antique City, touchscreen burial ceremony practice that provides investigation of Bronze Age objects and settlement, and 3 dimensional vase analysis of worldwide famous Hüseyindede Vase.

Eskişehir Hittite Archeology Museum is the home of stratified hologram practise that allows visitors to see sculptures which are seen from only one aspect from every aspect. Besides, virtual king grave visit in which there is King grave of Alpu Kocakızlar Tumulus that is recreated by means of 3 dimensional techniques, touchsecreen providing visitors to observe some small objects in the museum closely and to get interactive information, and 150x100 dimensional digital book practice that allows visitors turn the page by touching are presented to visitors.

Topkapt Palace Gun Collection is enriched with museum technologies. LCD TV informing screen on which various themed short animations and films about Ottoman military culture and weapon culture, 3 dimensional holograms of most famous Ottoman army figures Janissary, Cavalryman and Levents (Mariners), a big map and LCD TV which contains miniature recreations about Kosova, İstanbul, Ridaniye, Mohaç, Preveze, Kıbrıs and Bağdat wars that are presented on monitors on a giant map covering Meditarranean and Europe based on Piri Reis's Kitab-1 Bahriye are among the most attractive practices of the museum.

Alanya Archeology Museum uses a ship simulator in which visitors can have a trip on ship to historical Alanya Peninsula in order to inform visitors about the type of ships which came to Alanya through history. The person who uses the system can see historical Alanya and also watch the ships of civilisations that came to Alanya harbour through history (Byzantine dromon, Ottoman galley, Seljukian galiot, Maltese pirate ship, etc.). In Burdur Archeology Museum Kibyra Antique city is recreated in virtual platform, and there are kiosk controlled cylindirical screen that enables visitors to see the city from every aspect, 3D virtual object which 
provides the feeling of turning virtual potter's wheel and forming clay by touching the kiosk, and digital sculpture workplace allowing visitors to get information about sculptures and sculpturing techniques and containing a simple practice of one of these techniques. In Aydin Afrodisias Museum there is a kiosk which provides close observation of important art works, and a touchscreen that shows the art work of the era in Afrodisyas Ruins and contains a three dimensional interactive practice enabling a virtual trip in these places.

Antalya Archeology Museum prepared Antique Perge Theatre Information System. This system provides detailed information about 16 of the art works which were brought to the museum from Perge Antique Theatre. In this practice it is provided that visitors can investigate art works which were scanned by 3 dimensional scanner and the same as their originals from every aspect by touchscreen, and this vision is reflected on a projector screen. In Heracles Saloon visitors can learn 12 mission of Heracles on a touchscreen in the form of a book in an interactive presentation way. Also Hercules and the animals in the missions and mythological creatures are recreated in a way as it is in a traditional Karagöz shadow play. When visitors choose the sculpture they are interested in on the kiosk, the sculpture gets bigger in a way to allow visitors to observe clearly and provides a detailed information card. At the same time a 3 dimensional image of the chosen sculpture is reflected on the wall by a projector. 16 sculptures in Antique Perge Theatre were scanned by a 3 dimensional scanner and some corrections were made on them for this purpose. By rebuilding the original form of Perge Theatre as the way it was in use with the help of museum experts, it was recreated in a 3 dimensional way and the sculptures were put in their own places.

İstanbul Galata Mevlevi Dervishes Lodge and Konya Mevlana Museum are among attractive museums which are applied for museum technologies. 3D holographical image is places and there is a special room arrangement that provide to see a dervish from every aspect in Galata Mevlevi Dervishes Lodge. In Konya Mevlana Museum (Dervish Cells), there is a digital screen on which whirling dervishes greet and salute the visitors of the museum. Besides, there is a place for Mesnevi by Mevlana within the digital book system. Hologram practice about whirling dervishes and digital practices in which there are recreation of whirling dervish image, etc take place in the museum. In Kaman Archeology Museum (Kırşehir) there are $3 \mathrm{D}$ virtual object chosen from the seals that are exhibited in the museum and Kalehöyük virtual trip practice.

Aydın Archeology Museum presents its visitors Orthosia mosaics and an animation in which there is a 3 dimensional recreation of gladiator fights that were figured on those mosaics. LCD touchscreen which provides information to visitors about chosen art works and enables observation of these works from every aspect is also among museum technologies. The museum presents realistic sculpture presentation in which there is a recreation of an Antique Age coin minting workplace. In Edirne Turkish Islamic Works Museum, there is an animation in which Kirkpinar greased wrestling is recreated in 3 dimensional and a realistic sculpture recreation of Mimar Sinan. In Mardin Museum a 3D presentation film which provides audiences to get information about history of Mardin province and Mardin Museum, and a kiosk in which there is a digital map of Mardin province.

Table 1. List of museums and museum Technologies

\begin{tabular}{|c|c|c|}
\hline Museum & Province & Museum Technology \\
\hline $\begin{array}{l}\text { Etnographic } \\
\text { Museum }\end{array}$ & Ankara & $\begin{array}{c}\text { Virtual ceramic and glass } \\
\text { workplace,touchscreens, gun } \\
\text { holograms, 3D historical } \\
\text { characters. }\end{array}$ \\
\hline $\begin{array}{l}\text { State Art and } \\
\text { Sculpture } \\
\text { Museum }\end{array}$ & Ankara & $\begin{array}{l}\text { Digital book, 3D model of Art } \\
\text { and Sculpture Museum } \\
\text { building, kiosk, visual } \\
\text { catalogue, a digital binocular. }\end{array}$ \\
\hline Gordion Museum & Ankara & $\begin{array}{l}\text { Cylindirical screened virtual } \\
\text { visiting system, interactive } \\
\text { information system. }\end{array}$ \\
\hline $\begin{array}{l}\text { Zeugma Mosaic } \\
\text { Museum }\end{array}$ & Gaziantep & $\begin{array}{l}\text { Touchscreen informing screen, } \\
\text { 3D informing film, mosaic } \\
\text { completion practice, interactive } \\
\text { mosaic pool. }\end{array}$ \\
\hline $\begin{array}{l}\text { Kahramanmaraş } \\
\text { Museum }\end{array}$ & Kahramanmaraş & $\begin{array}{l}\text { Maraş elephant animations, 3D } \\
\text { panoramic simulation, 3D } \\
\text { Virtual terra cota mother } \\
\text { goddess sculpture. }\end{array}$ \\
\hline Çorum Museum & Çorum & $\begin{array}{c}\text { Hattuşa ancient city chariot } \\
\text { simulator, touchscreen panels, } \\
\text { Huseyindede vase digital } \\
\text { screen. }\end{array}$ \\
\hline $\begin{array}{l}\text { Eskişsehir Hittite } \\
\text { Archeology } \\
\text { Museum }\end{array}$ & Eskişehir & $\begin{array}{l}\text { Stratified hologram practise, } \\
\text { virtual king grave, 3D } \\
\text { techniques, touchsecreens, } \\
\text { digital book. }\end{array}$ \\
\hline Topkap1 Palace & İstanbul & $\begin{array}{l}\text { LCD TV informing scene, 3D } \\
\text { holograms, digital map of Piri } \\
\text { Reis. }\end{array}$ \\
\hline $\begin{array}{l}\text { Alanya } \\
\text { Archeology } \\
\text { Museum } \\
\end{array}$ & Antalya & Ship simulator. \\
\hline $\begin{array}{l}\text { Burdur } \\
\text { Archeology } \\
\text { Museum }\end{array}$ & Burdur & $\begin{array}{c}\text { Virtual platform, kiosk, 3D } \\
\text { virtual orbjects, virtual potter's } \\
\text { wheel, digital sculpture work } \\
\text { place. }\end{array}$ \\
\hline $\begin{array}{l}\text { Afrodisias } \\
\text { Archeology } \\
\text { Museum }\end{array}$ & Aydın & $\begin{array}{l}\text { Kiosk, touchscreens, 3D } \\
\text { interactive virtual trip. }\end{array}$ \\
\hline $\begin{array}{l}\text { Antalya } \\
\text { Archeology } \\
\text { Museum }\end{array}$ & Antalya & $\begin{array}{c}\text { Digital ancient Perge theatre } \\
\text { information, 3D scanners, } \\
\text { Herakles touchscreen digital } \\
\text { information, }\end{array}$ \\
\hline $\begin{array}{l}\text { Galata Mevlevi } \\
\text { Dervishes Lodge }\end{array}$ & İstanbul & 3D holographic Mevlevi image. \\
\hline $\begin{array}{l}\text { Konya Mevlana } \\
\text { Museum }\end{array}$ & Konya & $\begin{array}{c}\text { Digital screen of dervish cell, } \\
\text { digital book system holograph } \\
\text { practice. }\end{array}$ \\
\hline $\begin{array}{l}\text { Kaman } \\
\text { Archeology } \\
\text { Museum }\end{array}$ & Kırşehir & $\begin{array}{l}\text { 3D virtual objects (seals), } \\
\text { virtual trip. }\end{array}$ \\
\hline $\begin{array}{l}\text { Aydin } \\
\text { Archeology } \\
\text { Museum }\end{array}$ & Aydın & $\begin{array}{l}\text { 3D gladiator images, LCD } \\
\text { touchscreens, digital sculpture } \\
\text { presentation. }\end{array}$ \\
\hline $\begin{array}{c}\text { Edirne Turkish } \\
\text { Islamic Works } \\
\text { Museum } \\
\end{array}$ & Edirne & $\begin{array}{c}\text { Digital screen on Kirkpınar } \\
\text { greased wrestling, 3D sculpture } \\
\text { Mimar Sinan. }\end{array}$ \\
\hline Mardin Museum & Mardin & $\begin{array}{l}\text { 3D presentation film, kiosk, } \\
\text { digital map }\end{array}$ \\
\hline $\begin{array}{l}\text { Samsun City } \\
\text { Historical } \\
\text { Museum } \\
\end{array}$ & Samsun & $\begin{array}{l}\text { Digital book, 3D fish of Black } \\
\text { sea application. }\end{array}$ \\
\hline $\begin{array}{c}\text { Science and } \\
\text { Experiment } \\
\text { Centre } \\
\end{array}$ & Eskişehir & 3D alive painting practice. \\
\hline Marine Museum & İstanbul & $\begin{array}{c}\text { Digital Map of Piri Reis, digital } \\
\text { sea vehicles. }\end{array}$ \\
\hline $\begin{array}{l}\text { PTT National } \\
\text { Stamp Museum }\end{array}$ & Ankara & $\begin{array}{l}\text { Digital touchscreens, kiosks, } \\
\text { 3D holographic stamps. }\end{array}$ \\
\hline
\end{tabular}


Except from the museums that are tied to Ministry of Culture and Tourism, interactive museum practices are now being used in museums tied to municipalities. Interactive museum technologies in Samsun City Historical Museum are samples for this practice. Among interactive practices being used in the museum; a digital book in which the history of Samsun is told to visitors with photograps, and 3D Fish of Black Sea practice take place. This practice contains 3D modelled endemic fish species of Black Sea interactive practice in which informative bubbles about that fish appear when visitors touch on a fish, and which gives information to visitors on endangered fish species. Eskişehir Science Experiment Centre is a local authority enterprise and opened in Science, Art and Culture Park. In the entrance of Science Centre there is an "Alive Painting practice. Paintings talking to each other provide visitors a different experience at first sight and inform them. In this practice, leading scientists are modelled in 3D. Hypatia from Alexandria, Ali Kuşçu, Albert Einstein, Isaac Newton, Madam Curie and Rosalind Franklin are among these scientists. In Beşiktaş Marine Museum a $80 \mathrm{~m}^{2}$ giant effectvision practice for the maps of worldwide Turkish mariner Piri Reis was developed. Audiences are provided with some sea vehicles belonging to the time period of Piri Reis, and moving recreations of fantastic creatures which were in Piri Reis' maps and notes.

The Turkish Post and Telegraph Organization (PTT) celebrates 173 years of being in service with the inauguration of PTT National Stamp Museum including digital touch screens rekindle historical events through a vast stamp spectacle since the first issue in 1840 in Ankara. Old stamp collections, antique telephones, telegraphs and also clothes are exhibited in the museum. There are total of eight sets of clothing that flaunt a history of PTT employee fashion. The museum's 3D museum focuses on the organization's history.

The main exhibition room of the museum includes a touch screen desk allows visitors to journey through 100 years Turkish stamps, enriched by their stories. The stamps' historical account begins from 1900 to the modern day, focusing on notable events that occurred through time, with the 500th year of the conquest of Istanbul even receiving a place in stamp collection.

\section{Results}

Museum technologies in state museums tied to Ministry of Culture and Tourism and private museums inspected by the Ministry are supposed to provide free selective learning opportunities which were required by audiences. These technologies should be prepared connected with museum collection. Thus museum educators and experts are also supposed to have the grasp of this technology in order to run these programs which would be developed by the museum. The technologies being used in museums should be taught to visitors by experts who have the grasp of the subject and audiences should be couraged about the use of technology.

By doing audience research or identifying demand and needs of the participants, activities towards use of technology can be developed for every age group. In accordance with the idea of museum without walls, nowadays it has become a necessity to develop virtual (visual) museum activities for most museums. Virtual museum practices provide sustainability of museum technologies, and cause an increase in the number of the museum audience. Virtual museum practices are important educational tools for schools which do not have the opportunity to visit a museum in their cities or which look for opportunies of discovering different museums. Even educational units of museums should develop package educational programmes and present them to schools using virtual museum. At the same time, among these virtual practices it is possible to make museums more attactive by using games, puzzles, videos, animations, etc. which based on collections. Educational activities that would be realised by benefiting from technology support in some museums will reinforce similar technology use in different galleries of the same museums and even courage museums about technology use.

Museums should present their technologic facilities to public as a source of richness by using visual culture elements with the help of posters, billboards, TV and internet advertisements, and promoto these technologies. Also they can cooperate with some large companies and brands in technology market, and sign sponsorship contracts. They can provide technology funds by searching national and international projects. These initiatives will increase technological opportunities of museums and ease their accessibility. Museums that developed digital practices in accordance with their collections are expected to renew and upgrade these practices. So museums can develop a Research and Development Centre or technology units.

In new museum projects being practised in Turkey, a set of studies were started in order to address visitor perceptions and also provide educational opportunity based on objects by using facilities of information that has a scientific content and technology. As a result, in the museums of Turkey there has been a tendency towards the purpose of being for "person" by using various tools rather being for something. Technology revolution happening in the museums of Turkey also displays cultural heritage of Turkey to the world and carries museums to worldwide stand arts.

In this study, considering that almost all the aforesaid museums are directly subject to Ministry of Culture and Tourism and they are governed by state bureaucracy, it is seen that they are trying to use advanced technology as an important part of the understanding on modern museum studies. It should be emphasized that technologies used in museums are also important for providing sustainable visits to museums and at least for having an enjoyable museum visit. On the other hand, we can assume that the use of technology in museums is necessary not because other modern museums in the world use it but because an understanding which prioritizes visitor studies or visitor participation should be activated. Because, before a modern museum starts to use technology, it should complete the records of all inventory in its collection and have necessary policies about sharing information, education and public relations based on the awareness of its social functions. With reference to these developments, museums should make needs analysis in order to provide practices regarding technology and special to themselves. 
Besides, the existence of museums in virtual environments and social media and maintenance of this existence is as important as the use of technology in museums. Within this respect, the technologies used in museums which achieve their functions as necessary will surely provide the possibility to exhibit objects through virtual museums without any geographical boundaries; enable interaction between elements and people in virtual world by addressing to senses like sound, images and touching; help people to create their own meanings over objects by encouraging visitors' critical understanding through visual culture practices.

Some of the museums mentioned in this study don't have a web site independent from the Ministry of Culture and Tourism yet. Consequently, can these museums which aren't represented in social media and virtual world use their technological potency effectively to maintain both sustainable learning and visiting? The capacity of museum staff to use museum technologies and the fact that they can't offer service to visitors at any time as a result of present bureaucracy and density of job descriptions are important problems in terms of museum technologies. As long as the museums in Turkey don't empower their representation on social media, cooperation with schools isn't developed and practical and modern ways of reaching different parts of the society directly aren't used within social functions, unfortunately it is not possible to change elitist museum understanding among Turkish people and to positively develop museum habits that aren't settled yet. The priority of many museums in Turkey within the period of modernization is to enhance exhibition environments, to provide a variety of exhibitions and activities based on the cultural diversity in the country, to offer an active educational environment to the visitor (education is considered as the traditional function of museums nowadays) and to become accessible and green museums.

\section{References}

[1] Jameson, F.. Postmodernizm ya da geç kapitalizmin kültürel mantığı. Nirengikitap, Ankara, 2008, 420.

[2] Williams, R., Keyword: A Vocabolary of Culture and Society. Fontana Press, London, 1983.

[3] Monoghan, J., Just, P,. Social and Cultural Antrophology, A very short introduction. Oxford University Press Inc, New York, 2000.

[4] Delaney, C., Kaspin, D., (2011). Investigating Culture. 2nd Edition. Wiley-Blackwell Publishing, United Kingdom, 2011.

[5] Garoian C., and Gaudelius, Y., (2004). The Spectacle of Visual Culture Studies in Art Education, 45 (4) (2004), pp. 298-313

[6] Mitchell, W.,J.,T. Showing seeing: a critique of visual culture, in the visual culture reader, (ed. by Nicholas Mirzoeff). Routledge, London and New York, 2002, 86-102.

[7] Musneckine E. Visual culture discourses in the context of art education, Kürybos Erdves, 10, Lithhuania, 2009, 36-50.

[8] Duncum, P., "Visual culture art education: why, what and how?", International Journal of Art \& Design Education, 21 (1), February. 2002, 14-23.

[9] Djakovic, B., Rakovic, S. A museum of discomfort, in migration in museums: narratives of diversity in Europe (ed. Rainer Ohliger). Edition Network Migration in Europe, Berlin, 2009, 145.
[10] Leinhardt, G., Tittle, C., Knutson, K. Talking to oneself: diaries of museum visits. Museum learning collaborative technical report, 2000.

[11] Adams, G. Museums \& galleries: a teachers' handbook. Hutchinson, London, 1984.

[12] Sandell, R. The rural context. In Dodd, J. \& Sandell, R., (Eds.) including museums (pp. 95-97). Leicester: Research Centre for Museums and Galleries, Department of Museum Studies, University of Leicester, United Kingdom, 2001.

[13] Harrison, D., J. Ideas of museums in the 1990s. In George Corsane (Ed.), Heritage, museums and galleries: An introductory reader (pp. 38-53). Routledge, London, 2005. .

[14] Pearce, S. (Ed.). Objects of knowledge. London: Athone Press, London, 1992.

[15] Weil, S. (Ed.). Rethinking the museum. Smithsonian Inst, Washington, 1990.

[16] Ambrose, T., Paine, C. Museum basics. (2nd ed.). Routledge, London, 2006.

[17] Talboys, K., G. Museum educator's handbook. (2nd ed.). Ashgate Publishing, United Kingdom, 2006.

[18] Ambrose, T., Paine, C. Museum basics. (2nd ed.). Routledge, London, 2006.

[19] Hooper-Greenhill, E. Museums and the interpretation of visual culture. Routledge, New York, 2000.

[20] Adams, G. Museums and Galleries: A Teachers' Handbook. Hutchinson, London, 1984.

[21] Hooper-Greenhill, E. Museums and The Interpretation of Visual Culture, New York, Routledge, 2000.

[22] Freedman, K., "Teaching visual culture curriculum, aesthetics and the social life of art”,(Teachers Collage, Columbia University New York and London-National Art Education Association), 2003, 11, London.

[23] Çalıkoğlu, L., Yeni bir dikkat alanı: koleksiyon-koleksiyonerlik ve müzecilik, Çağdaş sanat konuşmaları-4, Yapı Kredi Yayınları, İstanbul, 2009.

[24] Artun, A. Tarih sahneleri- sanat müzeleri 1, müze ve modernlik. İletişim Yayınları, İstanbul, 2006.

[25] Berger, J., (1993). Görme biçimleri. 5. Baskı. Metis Yayınları, İstanbul.

[26] Huyssen, A., "Bellek yitiminden kaçış: kitle iletişim aracı olarak müze”, Tarih Sahneleri - Sanat Müzeleri 2: Müze ve Eleştirel Düşünce içinde (Ed. Ali Artun), İletişim Yayınları, İstanbul, 2006.

[27] Silvers, A., (2004). Pedagogy and Polemics: Are Art Educators Qualified to Teach Visual Culture, Arts Education and Visual Culture Studies Symphosium, Arts Education Policy Review, 106: $1,19-24$, USA.

[28] Çoruh, L., (2011) "Sanat Tarihi Dersinde Bir Öğrenme Modeli Olarak Sanal Gerçeklik Uygulamasının Etkililiğinin Değerlendirilmesi (Erciyes Üng̉versitesi Mimarlık Ve Güzel Sanatlar Fakülteleri Örneği Uygulaması)”, Yayımlanmamış Doktora Tezi (Doctorate Dissertation), Gazi Üniversitesi Eğitim Bilimleri Enstitüsü Uygulamalı Sanatlar Eğitimi Bölümü Grafik Eğitimi Anabilim Dalı, Ankara, p. 47-72.

[29] Karadeniz, C., Çıldır, Z. İngiltere'de müze eğitimi: Londra'dan izlenimler. KalemKitap Yayınevi, Ankara, 2014.

[30] Schweibenz, W. The Development of Virtual Museums. ICOM News No: 3. 2004. [Online]. Available: http://icom.museum/fileadmin/user_upload/pdf/ICOM_News/200 4-3/ENG/p3_2004-3.pdf [Accessed: 25. 08. 2012]

[31] Çolak, C. (2006). Sanal Müzeler. Türkiye'de İnternet Konferansı (21-23. 12. 2006). [Online]. Available: http://inettr.org.tr/inetconf11/bildiri/ [Accessed: 03. 06. 2014].

[32] Türkiye'nin Müzeleri. Değiş̧en ve Gelişen Türkiye Müzeleri: Uygulama ve Proje Çalışmaları ve Proje Çalışmaları Devam Eden Yeni Müzeler. T.C. Kültür ve Turizm Bakanlığı Kültür Varlıkları ve Müzeler Genel Müdürlüğü Yayınları, Ankara, 2013.

[33] REO-TEK Simülasyon, Etkileşimli Sunum ve Sergi Tasarımı offical web page. [Online]. Available: http://www.reo-tek.com [Accessed: 03. 06. 2014]. 